Article

\title{
Norcembranoidal Diterpenes from a Formosan Soft Coral Sinularia sp.
}

\author{
Wei-Hsuan Yen ${ }^{1,2}$, Li-Chung Hu ${ }^{1,2}$, Jui-Hsin Su ${ }^{1,2,3}$, Mei-Chin Lu ${ }^{1,2}$, Wen-Hung Twan ${ }^{4}$, \\ Show-Ying Yang ${ }^{5}$, Yung-Chi Kuo ${ }^{5}$, Ching-Feng Weng ${ }^{1}$, Chia-Hung Lee ${ }^{1}$, Yueh-Hsiung Kuo ${ }^{6, *}$ \\ and Ping-Jyun Sung $1,2,3,7, *$
}

1 Graduate Institute of Marine Biotechnology and Department of Life Science and Institute of Biotechnology, National Dong Hwa University, Pingtung 944, Taiwan;

E-Mails: xyz78714@hotmail.com (W.-H.Y.); stoja582@gmail.com (L.-C.H.);

x2219@nmmba.gov.tw (J.-H.S.); jinx6609@nmmba.gov.tw (M.-C.L.);

cfweng@mail.ndhu.edu.tw (C.-F.W.); chlee016@mail.ndhu.edu.tw (C.-H.L.)

2 National Museum of Marine Biology and Aquarium, Pingtung 944, Taiwan

3 Division of Marine Biotechnology, Department of Marine Biotechnology and Resources, Asia-Pacific Ocean Research Center, National Sun Yat-sen University, Kaohsiung 833, Taiwan

4 Department of Life Science, National Taitung University, Taitung 950, Taiwan;

E-Mail: twan@nttu.edu.tw

5 Industrial Technology Research Institute, Clean Energy and Eco-Technology Center, Tainan 734,

Taiwan; E-Mails: yangsy@itri.org.tw (S.-Y.Y.); itriA10063@itri.org.tw (Y.-C.K.)

6 Tsuzuki Institute for Traditional Medicine, China Medical University, Taichung 404, Taiwan

7 Graduate Institute of Natural Products, Kaohsiung Medical University, Kaohsiung 807, Taiwan

* Authors to whom correspondence should be addressed; E-Mails: kuoyh@mail.cmu.edu.tw (Y.-H.K.); pjsung@nmmba.gov.tw (P.-J.S.); Tel./Fax: +886-4-2207-1693 (Y.-H.K.);

Tel.: +886-8-882-5037 (P.-J.S.); Fax: +886-8-882-5087 (P.-J.S.).

Received: 22 October 2012; in revised form: 18 November 2012 / Accepted: 23 November 2012 / Published: 27 November 2012

\begin{abstract}
Two norcembranoidal diterpenes, 5-episinuleptolide acetate (1) and scabrolide D (2), were isolated from a Formosan octocoral identified as Sinularia sp. The structures of norcembranoids $\mathbf{1}$ and $\mathbf{2}$ were established by spectroscopic methods and by comparison of the spectral data with those of known analogues and $\mathbf{1}$ was proven to be a new natural product. Norcembranoid 1 was found to exhibit cytotoxicity toward a panel of tumor cells.
\end{abstract}


Keywords: Sinularia; norcembranoidal diterpene; cytotoxicity

\section{Introduction}

The search for bioactive natural products from marine organisms has been remarkably successful [1,2] and octocorals belonging to the genus Sinularia have proven to be rich sources of bioactive terpenoid analogues [3]. Among these terpenoid metabolites, the $\mathrm{C}_{19}$-norcembranoid diterpene derivatives played an important role [4]. In continuation of our search for new natural substances from the marine invertebrates collected off the waters of Taiwan at the intersection of the Kuroshio current and the South China Sea surface current, we have further isolated two norcembranoidal diterpenes, 5-episinuleptolide acetate (1) and scabrolide D (2), from an octocoral identified as Sinularia sp. (Figure 1). In this paper, we describe the isolation, structure determination and cytotoxicity of norcembranoids $\mathbf{1}$ and $\mathbf{2}$.

Figure 1. The soft coral Sinularia sp. and the structures of 5-episinuleptolide acetate (1) and scabrolide D (2).

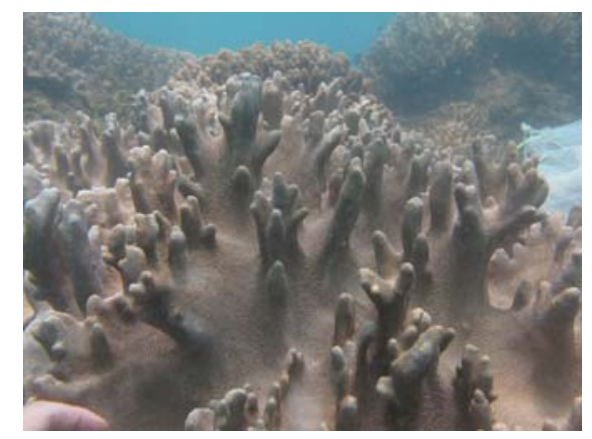

Sinularia sp.

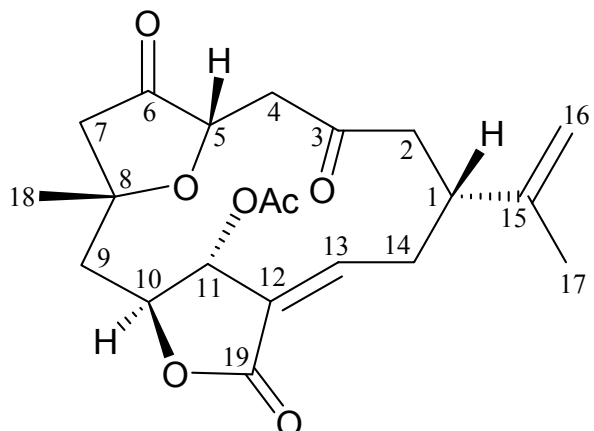

1

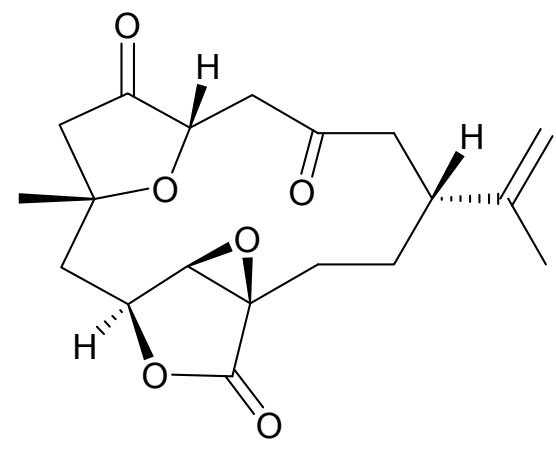

2

\section{Results and Discussion}

The molecular formula for norcembranoidal diterpene 1 was determined to be $\mathrm{C}_{21} \mathrm{H}_{26} \mathrm{O}_{7}$ (nine units of unsaturation) using HRESIMS $\left(\mathrm{C}_{21} \mathrm{H}_{26} \mathrm{O}_{7}+\mathrm{Na}, m / z\right.$ 413.1574, calculated 413.1576). The IR spectrum of 1 showed strong bands at 1756,1738 and $1719 \mathrm{~cm}^{-1}$, consistent with the presence of ester and ketone carbonyl groups. From the ${ }^{1} \mathrm{H}$ - and ${ }^{13} \mathrm{C}$-NMR spectra (Table 1), 1 was found to possess an 
acetoxy group $\left(\delta_{\mathrm{H}} 2.08,3 \mathrm{H}, \mathrm{s} ; \delta_{\mathrm{C}} 171.2, \mathrm{C} ; 20.9, \mathrm{CH}_{3}\right)$, an ester group $\left(\delta_{\mathrm{C}} 167.7, \mathrm{C}-19\right)$ and two ketone carbonyls $\left(\delta_{\mathrm{C}} 205.3, \mathrm{C}-3 ; 214.5, \mathrm{C}-6\right)$. Two additional unsaturated functionalities were indicated by ${ }^{13} \mathrm{C}$ resonances at $\delta_{\mathrm{C}} 127.6$ (C-12), $147.2(\mathrm{CH}-13), 147.0$ (C-15) and $110.4(\mathrm{CH} 2-16)$, suggesting the presence of a trisubstituted olefin and an exocyclic carbon-carbon double bond. From the ${ }^{1} \mathrm{H}-{ }^{1} \mathrm{H}$ COSY spectrum of $\mathbf{1}$ (Table 1 and Figure 2), it was possible to differentiate among the separate spin systems of $\mathrm{H}-1 / \mathrm{H}_{2}-2, \mathrm{H}_{2}-4 / \mathrm{H}-5, \mathrm{H}_{2}-9 / \mathrm{H}-10 / \mathrm{H}-11, \mathrm{H}-13 / \mathrm{H}_{2}-14 / \mathrm{H}-1$ and $\mathrm{H}_{2}-16 / \mathrm{H}_{3}-17$ (by allylic coupling). These data, together with the key HMBC correlations between protons and quaternary carbons of 1 (Table 1 and Figure 2), such as $\mathrm{H}_{2}-2, \mathrm{H}_{2}-4, \mathrm{H}-5 / \mathrm{C}-3 ; \mathrm{H}_{2}-4, \mathrm{H}_{2}-7 / \mathrm{C}-6 ; \mathrm{H}_{2}-7$, $\mathrm{H}_{2}-9, \mathrm{H}-10, \mathrm{H}_{3}-18 / \mathrm{C}-8$; H-11, $\mathrm{H}_{2}-14 / \mathrm{C}-12 ; \mathrm{H}-1, \mathrm{H}_{2}-2, \mathrm{H}_{2}-14, \mathrm{H}_{2}-16, \mathrm{H}_{3}-17 / \mathrm{C}-15$; and H-10, H-11, $\mathrm{H}-13 / \mathrm{C}-19$, permitted the elucidation of the carbon skeleton. The acetoxy group positioned at $\mathrm{C}-11$ was confirmed from the HMBC correlations of $\mathrm{H}-11\left(\delta_{\mathrm{H}} 5.47\right)$ and protons of an acetate methyl ( $\delta_{\mathrm{H}} 2.08$ ) to the ester carbonyl carbon at $\delta_{\mathrm{C}} 171.2(\mathrm{C})$. Thus, 1 was revealed as a norcembranoidal diterpene possessing a $\gamma$-lactone ring, on the basis of the above analysis.

Table 1. ${ }^{1} \mathrm{H}\left(400 \mathrm{MHz}, \mathrm{CDCl}_{3}\right)$ and ${ }^{13} \mathrm{C}\left(100 \mathrm{MHz}, \mathrm{CDCl}_{3}\right) \mathrm{NMR}$ data, ${ }^{1} \mathrm{H}-{ }^{1} \mathrm{H}$ COSY and HMBC correlations for norcembranoidial diterpene 1.

\begin{tabular}{|c|c|c|c|c|}
\hline Position & $\delta_{\mathrm{H}}(J$ in $\mathrm{Hz})$ & $\delta_{\mathrm{C}}$, Mult. & ${ }^{1} \mathrm{H}-{ }^{1} \mathrm{H} \mathrm{COSY}$ & HMBC $(\mathrm{H} \rightarrow \mathrm{C})$ \\
\hline 1 & $2.99 \mathrm{~m}$ & $39.6, \mathrm{CH}$ & $\mathrm{H}_{2}-2, \mathrm{H}_{2}-14$ & C-15 \\
\hline $2 \alpha$ & $2.65 \mathrm{~m}$ & $45.9, \mathrm{CH}_{2}$ & $\mathrm{H}-1, \mathrm{H}-2 \beta$ & $C-1,-3,-14,-15$ \\
\hline$\beta$ & $2.52 \mathrm{~m}$ & & $H-1, H-2 \alpha$ & $C-1,-3,-14,-15$ \\
\hline 3 & & $205.3, \mathrm{C}$ & & \\
\hline $4 \alpha$ & $2.53 \mathrm{dd}(16.4,8.8)$ & $43.1, \mathrm{CH}_{2}$ & $\mathrm{H}-4 \beta, \mathrm{H}-5$ & $C-3,-5,-6$ \\
\hline$\beta$ & $2.82 \mathrm{dd}(16.4,2.4)$ & & $\mathrm{H}-4 \alpha, \mathrm{H}-5$ & $C-3,-5,-6$ \\
\hline 5 & $4.27 \mathrm{dd}(8.8,2.4)$ & $75.0, \mathrm{CH}$ & $\mathrm{H}_{2}-4$ & $\mathrm{C}-3,-4$ \\
\hline 6 & & $214.5, \mathrm{C}$ & & \\
\hline $7 \alpha$ & $2.60 \mathrm{~m}$ & $51.1, \mathrm{CH}_{2}$ & $\mathrm{H}-7 \beta$ & $C-5,-6,-8,-9,-18$ \\
\hline$\beta$ & $2.46 \mathrm{~m}$ & & $\mathrm{H}-7 \alpha$ & $C-5,-6,-8,-9,-18$ \\
\hline 8 & & 79.0, C & & \\
\hline $9 \alpha$ & $2.34 \mathrm{~m}$ & $41.8, \mathrm{CH}_{2}$ & H-9 $\beta, \mathrm{H}-10$ & $C-7,-8,-10,-11,-18$ \\
\hline$\beta$ & $2.47 \mathrm{~m}$ & & $H-9 \alpha, H-10$ & $C-7,-8,-10,-11,-18$ \\
\hline 10 & $4.52 \mathrm{dt}(6.8,2.0)$ & $80.8, \mathrm{CH}$ & $\mathrm{H}_{2}-9, \mathrm{H}-11$ & $\mathrm{C}-8,-11,-19$ \\
\hline 11 & 5.47 br s & $76.4, \mathrm{CH}$ & $\mathrm{H}-10$ & C-9, $-12,-13,-19$, acetate carbonyl \\
\hline 12 & & 127.6, C & & \\
\hline 13 & $6.45 \operatorname{ddd}(10.8,4.4,1.2)$ & $147.2, \mathrm{CH}$ & $\mathrm{H}_{2}-14$ & $\mathrm{C}-1,-11,-19$ \\
\hline $14 \alpha$ & $2.20 \operatorname{ddd}(14.8,4.4,3.6)$ & $28.4, \mathrm{CH}_{2}$ & $\mathrm{H}-1, \mathrm{H}-13$ & $C-1,-2,-12,-13,-15$ \\
\hline$\beta$ & 3.78 ddd $(14.8,10.8,6.8)$ & & $\mathrm{H}-1, \mathrm{H}-13$ & $C-1,-2,-12,-13,-15$ \\
\hline 15 & & 147.0, C & & \\
\hline $16 a$ & $4.86 \mathrm{~s}$ & $110.4, \mathrm{CH}_{2}$ & $\mathrm{H}-16 \mathrm{~b}, \mathrm{H}_{3}-17$ & $C-1,-15,-17$ \\
\hline $\mathrm{b}$ & $4.79 \mathrm{~s}$ & & $\mathrm{H}-16 \mathrm{a}, \mathrm{H}_{3}-17$ & $\mathrm{C}-1,-15,-17$ \\
\hline 17 & $1.80 \mathrm{~s}$ & $21.6, \mathrm{CH}_{3}$ & $\mathrm{H}_{2}-16$ & $C-1,-15,-16$ \\
\hline 18 & $1.42 \mathrm{~s}$ & $26.5, \mathrm{CH}_{3}$ & & $\mathrm{C}-7,-8,-9$ \\
\hline 19 & & 167.7, C & & \\
\hline 11-OAc & & 171.2, C & & \\
\hline & $2.08 \mathrm{~s}$ & $20.9, \mathrm{CH}_{3}$ & & Acetate carbonyl \\
\hline
\end{tabular}


Figure 2. The ${ }^{1} \mathrm{H}-{ }^{1} \mathrm{H}$ COSY and key HMBC (protons $\rightarrow$ quaternary carbons) correlations for $\mathbf{1}$.

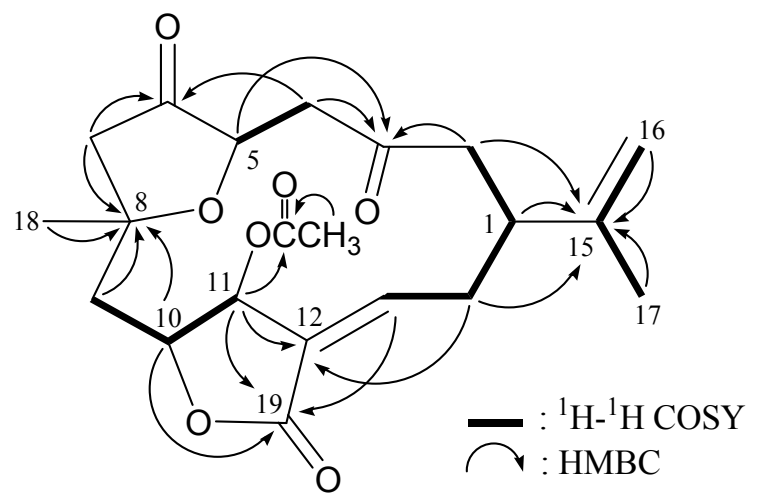

The relative configuration of $\mathbf{1}$ was elucidated mainly from a NOESY spectrum as being compatible with that of 1 offered by computer modeling (Figure 3), in which the close contacts of atoms in space calculated were consistent with the NOESY correlations [5]. Most naturally occurring cembrane-type natural products from soft coral belonging to the order Alcyonacea have the H-1 in the $\beta$-orientation [6]. In the NOESY experiment for $1, \mathrm{H}-1$ correlated with $\mathrm{H}_{2}-14$ and one proton of C-2 methylene $\left(\delta_{\mathrm{H}} 2.52\right.$, $\mathrm{H}-2 \beta)$, supporting this reasoning by molecular modeling analysis. H-13 showed correlations with $\mathrm{H}-2 \alpha\left(\delta_{\mathrm{H}} 2.65\right), \mathrm{H}-11$ and one proton of $\mathrm{C}-14$ methylene $\left(\delta_{\mathrm{H}} 2.20, \mathrm{H}-14 \alpha\right)$, but not with $\mathrm{H}-1$, indicating the $E$-configuration of the $\mathrm{C}-12 / 13$ double bond. $\mathrm{H}-10$ showed a correlation with $\mathrm{H}-11$, as well as the lack of coupling was detected between these two protons, indicating the dihedral angle between $\mathrm{H}-10$ and $\mathrm{H}-11$ is approximately $90^{\circ}$ and the configurations of chiral carbons C-10 and C-11 were assigned as $S^{*}$ - and $R^{*}$-forms, respectively. One proton of C-9 methylene $\left(\delta_{\mathrm{H}} 2.47\right)$ correlated with $\mathrm{H}-10$ and $\mathrm{H}_{3}-18$, but not with $\mathrm{H}-11$, and $\mathrm{H}_{3}-18$ showed a strong correlation with $\mathrm{H}-5$, indicating that Me- 18 and H-5 were $\beta$-oriented in 1 . From the above evidences, the relative configuration of the chiarl carbons of 1 were assumed to be $1 R^{*}, 5 S^{*}, 8 R^{*}, 10 S^{*}$ and $11 R^{*}$.

Figure 3. The computer-generated model of 1 using MM2 force field calculations and the calculated distances $(\AA)$ between selected protons with key NOESY correlations.

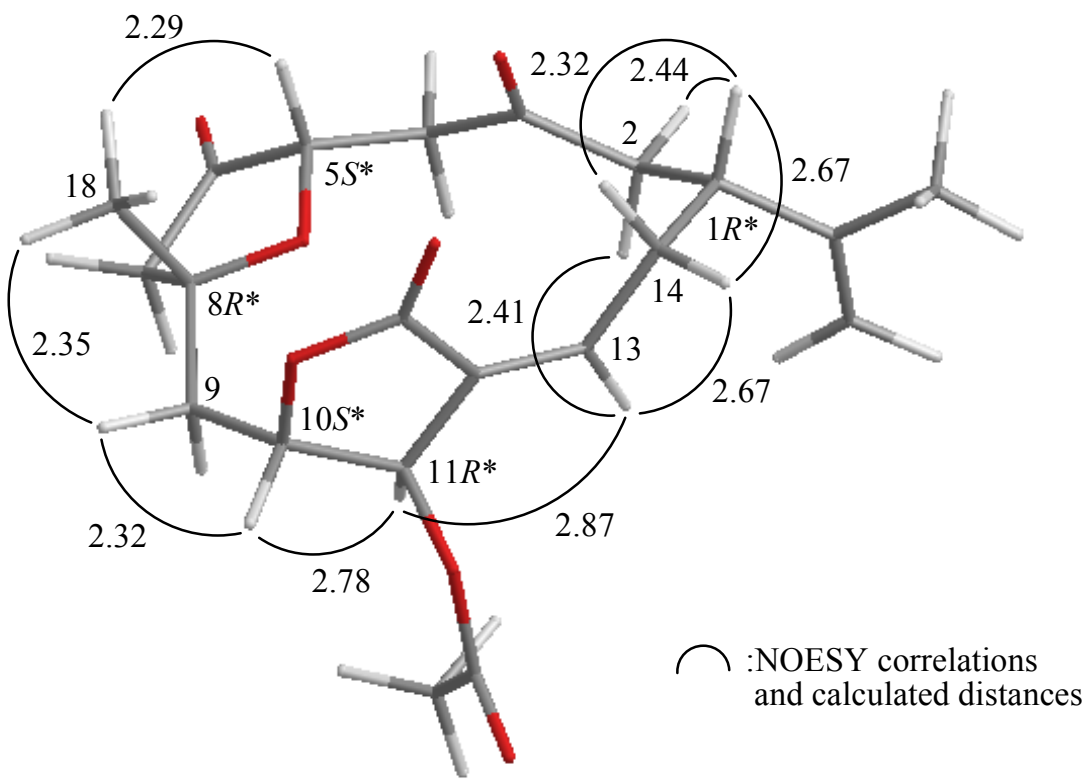


By comparison of the spectral data with those of a known semisynthetic diterpene, compound $\mathbf{1}$ was elucidated unambiguously to be 5-episinuleptolide acetate [7]. To the best of our knowledge, norcembranoidal diterpene $\mathbf{1}$ was isolated for the first time from a natural source.

Norcembranoidial diterpene $\mathbf{2}$ was identified as scabrolide D, which had been isolated from a Formosan octocoral Sinularia scabra. Its spectral data were in full agreement with those previously reported [8].

Cytotoxicity of the norcembranoidal diterpenes 1 and 2 toward K562 (human erythromyeloblastoid leukemia), MOLT-4 (human acute lymphoblastic leukemia), HTC-116 (human acute promyelocytic leukemia), DLD-1 (human colorectal adenocarcinoma), T-47D (human breast ductal carcinoma) and MDA-MB-231 (human breast adenocarcinoma) cells was studied, and the results are shown in Table 2. These data showed that compound 1 (5-episinuleptolide acetate) exhibited modest cytotoxicity towards all the cells.

Table 2. Cytotoxic data of norcembranoidal diterpenes $\mathbf{1}$ and $\mathbf{2 .}$

\begin{tabular}{ccccccc}
\hline Compounds & \multicolumn{6}{c}{ Cell lines $\mathbf{I C}_{\mathbf{5 0}}(\boldsymbol{\mu g} / \mathbf{m L})$} \\
\cline { 2 - 7 } & $\mathbf{K 5 6 2}$ & MOLT-4 & HTC-116 & DLD-1 & T-47D & MDA-MB-231 \\
\hline $\mathbf{1}$ & 0.67 & 0.59 & 4.09 & 0.92 & 3.09 & 2.95 \\
$\mathbf{2}$ & NA & NA & NA & NA & NA & NA \\
Doxorubicin $^{a}$ & 0.15 & 0.01 & 1.11 & 0.22 & 0.40 & 1.30 \\
\hline
\end{tabular}

${ }^{a}$ Doxorubicin was used as positive control. NA $=$ not active at $20 \mu \mathrm{g} / \mathrm{mL}$ for $72 \mathrm{~h}$.

\section{Experimental}

\subsection{General Procedures}

Optical rotation values were measured with a Jasco-P1010 digital polarimeter. Infrared spectra were obtained on a Varian Diglab FTS 1000 FT-IR spectrophotometer. NMR spectra were recorded on a Varian Mercury Plus $400 \mathrm{FT}-\mathrm{NMR}$ at $400 \mathrm{MHz}$ for ${ }^{1} \mathrm{H}$ and $100 \mathrm{MHz}$ for ${ }^{13} \mathrm{C}$ in $\mathrm{CDCl}_{3}$ at $25{ }^{\circ} \mathrm{C}$. Proton chemical shifts were referenced to the residual $\mathrm{CHCl}_{3}$ signal $\left(\delta_{\mathrm{H}} 7.26 \mathrm{ppm}\right) .{ }^{13} \mathrm{C}-\mathrm{NMR}$ spectra were referenced to the center peak of $\mathrm{CDCl}_{3}$ at $\delta_{\mathrm{C}} 77.1 \mathrm{ppm}$. ESIMS and HRESIMS data were recorded on Bruker APEX II mass spectrometer. Column chromatography was performed on silica gel (230-400 mesh, Merck, Darmstadt, Germany). TLC was carried out on precoated Kieselgel $60 \mathrm{~F}_{254}(0.25 \mathrm{~mm}$, Merck) and spots were visualized by spraying with $10 \% \mathrm{H}_{2} \mathrm{SO}_{4}$ solution followed by heating. HPLC was performed using a system comprised of a Hitachi L-7100 pump, a Hitachi L-7455 photodiode array detector and a Rheodyne 7725 injection port. A normal phase column (Hibar $250 \times 10 \mathrm{~mm}$, Merck, silica gel 60, $5 \mu \mathrm{m}$ ) was used for HPLC.

\subsection{Animal Material}

Specimens of the soft coral Sinularia sp. were collected by hand using scuba equipment off the coast of Sansiantai, Taitung County, Taiwan in October 13, 2011, and stored in a freezer $\left(-20{ }^{\circ} \mathrm{C}\right)$ until extraction. This organism was identified by comparison with previous descriptions [9]. A voucher specimen was deposited in the National Museum of Marine Biology and Aquarium, Taiwan. 


\subsection{Extraction and Isolation}

The freeze-dried and mince material of Sinularia sp. (wet weight $1.30 \mathrm{~kg}$, dry weight $328 \mathrm{~g}$ ) was extracted with ethyl acetate $\left(\right.$ EtOAc) at $25{ }^{\circ} \mathrm{C}(2 \mathrm{~L} \times 10)$. The EtOAc extract left after removal of the solvent (11.4 g) was separated by silica gel and eluted using $n$-hexane/EtOAc in a stepwise fashion from 100:1 to pure EtOAc to yield 13 fractions A-M. Fraction $\mathrm{H}$ was separated by normal-phase HPLC (NP-HPLC) using a mixture of $n$-hexane and EtOAc (9:4) as the mobile phase to afford compounds 1 (29.5 mg) and 2 (4.4 mg).

5-Episinuleptolide acetate $(\mathbf{1}):[\alpha]_{\mathrm{D}}^{25}-81\left(c \quad 0.5, \mathrm{CHCl}_{3}\right)$; IR (neat) $v_{\max } 1756,1738,1719 \mathrm{~cm}^{-1}$; ${ }^{1} \mathrm{H}-\left(\mathrm{CDCl}_{3}, 400 \mathrm{MHz}\right)$ and ${ }^{13} \mathrm{C}-\left(\mathrm{CDCl}_{3}, 100 \mathrm{MHz}\right) \mathrm{NMR}$ data, see Table 1; ESIMS $\mathrm{m} / z 413[\mathrm{M}+\mathrm{Na}]^{+}$; HRESIMS: $m / z 413.1574$ (calcd for $\mathrm{C}_{21} \mathrm{H}_{26} \mathrm{O}_{7}+\mathrm{Na}, 413.1576$ ).

Scabrolide D (2): $[\alpha]_{\mathrm{D}}^{25}-67$ (c 0.2, $\mathrm{CHCl}_{3}$ ); IR (neat) $v_{\max } 1775,1762,1711 \mathrm{~cm}^{-1} ;{ }^{1} \mathrm{H}-$ and ${ }^{13} \mathrm{C}-\mathrm{NMR}$ spectral data were found to be in full agreement with those of reported previously [8].

\subsection{Molecular Mechanics Calculations}

Implementation of the MM2 force field [5] in CHEM3D PRO software from CambridgeSoft Corporation (Cambridge, MA, USA; ver. 9.0, 2005) was used to calculate molecular models.

\subsection{Cytotoxicity Testing}

The cytotoxicity of norcembranoidal diterpenes $\mathbf{1}$ and $\mathbf{2}$ was assayed with a modification of the MTT [3-(4,5-dimethylthiazol-2-yl)-2,5-diphenyltetrazolium bromide] colorimetric method. Cytotoxicity assays were carried out according to previously described procedures [10,11].

\section{Conclusions}

Cembrane- and norcembrane-type natural products are major constituents of the extracts of Sinularia spp. octocorals distributed in the waters off Taiwan [8,12-35]. Our continuing studies on the chemical constituents of a wild-type soft coral Sinularia sp. has led to the isolation of a new natural product, 5-episinuleptolide acetate (1), which was found to exhibit modest cytotoxicity against K562, MOLT-4, HTC-116, DLD-1, T-47D and MDA-MB-231 tumor cells. This study suggested that 5-episinuleptolide acetate (1) is worthy of further biomedical investigation. The study material Sinularia sp. has begun to be transplanted to culturing tanks with a flow-through sea water system located in the National Museum of Marine Biology and Aquarium, Taiwan for the extraction of additional natural products in order to establish a stable supply of bioactive material.

\section{Acknowledgments}

This work was supported by grants from the National Dong Hwa University; the National Museum of Marine Biology and Aquarium (Grant No. 10120022); the Division of Marine Biotechnology, Asia-Pacific Ocean Research Center, National Sun Yat-sen University, (Grant No. 00C-0302-05); the Department of Health Clinical Trial and Research Center of Excellence (Grant No. DOH101-TD-C-111-004); 
and the National Science Council (Grant No. NSC 101-2325-B-291-001, 100-2325-B-291-001, 101-2320-B-291-001-MY3 and 98-2320-B-291-001-MY3), Taiwan, awarded to Y.-H.K. and P.-J.S.

\section{References}

1. Molinski, T.F.; Dalisay, D.S.; Lievens, S.L.; Saludes, J.P. Drug development from marine natural products. Nat. Rev. Drug Discov. 2009, 8, 69-85.

2. Rocha, J.; Peixe, L.; Gomes, N.C.M.; Calado, R. Cnidarians as a new marine bioactive compounds-An overview of the last decade and future steps for bioprospecting. Mar. Drugs 2011, 9, 1860-1886.

3. Chen, W.-T.; Li, Y.; Guo, Y.-W. Terpenoids of Sinularia soft corals: Chemistry and bioactivity. Acta Pharm. Sinica B 2012, 2, 227-237.

4. Li, Y.; Pattenden, G. Novel macrocyclic and polycyclic norcembranoid diterpenes from Sinularia species of soft coral: structural relationships and biosynthetic speculations. Nat. Prod. Rep. 2011, $28,429-440$.

5. Allinger, N.L. Conformational analysis. 130. MM2. A hydrocarbon force field utilizing $V_{1}$ and $V_{2}$ torsional terms. J. Am. Chem. Soc. 1977, 99, 8127-8134.

6. Rodríguez, A.D.; Li, Y.; Dhasmana, H.; Barnes, C.L. New marine cembrane diterpenoids isolated from the Caribbean gorgonian Eunicea mammosa. J. Nat. Prod. 1993, 56, 1103-1113.

7. Li, Y.; Pattenden, G. Biomimetic syntheses of ineleganolide and sinulochmodin C from 5-episinuleptolide via sequences of transannular Michael reactions. Tetrahedron 2011, 67, 10045-10052.

8. Sheu, J.-H.; Ahmed, A.F.; Shiue, R.-T.; Dai, C.-F.; Kuo, Y.-H. Scabrolides A-D, four new norditerpenoids isolated from the soft coral Sinularia scabra. J. Nat. Prod. 2002, 65, 1904-1908.

9. Bayer, F.M. Key to the genera of Octocorallia exclusive of Pennatulacea (Coelenterata: Anthozoa), with diagnoses of new taxa. Proc. Biol. Soc. Wash. 1981, 94, 902-947.

10. Alley, M.C.; Scudiero, D.A.; Monks, A.; Hursey, M.L.; Czerwinski, M.J.; Fine, D.L.; Abbott, B.J.; Mayo, J.G.; Shoemaker, R.H.; Boyd, M.R. Feasibility of drug screening with panels of human tumor cell lines using a microculture tetrazolium assay. Cancer Res. 1988, 48, 589-601.

11. Scudiero, D.A.; Shoemaker, R.H.; Paull, K.D.; Monks, A.; Tierney, S.; Nofziger, T.H.; Currens, M.J.; Seniff, D.; Boyd, M.R. Evaluation of a soluble tetrazolium/formazan assay for cell growth and drug sensitivity in culture using human and other tumor cell lines. Cancer Res. 1988, $48,4827-4833$.

12. Chao, C.-H.; Chou, K.-J.; Huang, C.-Y.; Wen, Z.-H.; Hsu, C.-H.; Wu, Y.-C.; Dai, C.-F.; Sheu, J.-H. Bioactive cembranoids from the soft coral Sinularia crassa. Mar. Drugs 2011, 9, 1955-1968.

13. Lin, Y.-S.; Lee, N.-L.; Lu, M.-C.; Su, J.-H. Two new cembrane-based diterpenoids from the marine soft coral Sinularia crassa. Molecules 2012, 17, 5422-5429.

14. Lu, Y.; Su, H.-J.; Chen, Y.-H.; Wen, Z.-H.; Sheu, J.-H.; Su, J.-H. Anti-inflammatory cembranoids from the Formosan soft coral Sinularia discrepans. Arch. Pharm. Res. 2011, 34, 1263-1267.

15. Duh, C.-Y.; Wang, S.-K.; Tseng, H.-K.; Sheu, J.-H.; Chiang, M.Y. Novel cytotoxic cembranoids from the soft coral Sinularia flexibilis. J. Nat. Prod. 1998, 61, 844-847. 
16. Duh, C.-Y.; Wang, S.-K.; Tseng, H.-K.; Sheu, J.-H. A novel cytotoxic biscembranoid from the Formosan soft coral Sinularia flexibilis. Tetrahedron Lett. 1998, 39, 7121-7122.

17. Hsieh, P.-W.; Chang, F.-R.; McPhail, A.T.; Lee, K.-H.; Wu, Y.-C. New cembranolide analogues from the Formosan soft coral Sinularia flexibilis and their cytotoxicity. Nat. Prod. Res. 2003, 17, 409-418.

18. Su, J.-H.; Lin, Y.-F.; Lu, Y.; Yeh, H.-C.; Wang, W.-H.; Fan, T.-Y.; Sheu, J.-H. Oxygenated cembranoids from the cultured and wild-type soft corals Sinularia flexibilis. Chem. Pharm. Bull. 2009, 57, 1189-1192.

19. Lin, Y.-S.; Chen, C.-H.; Liaw, C.-C.; Chen, Y.-C.; Kuo, Y.-H.; Shen, Y.-C. Cembrane diterpenoids from the Taiwanese soft coral Sinularia flexibilis. Tetrahedron 2009, 65, 9157-9164.

20. Lo, K.-L.; Khalil, A.T.; Kuo, Y.-H.; Shen, Y.-C. Sinuladiterpenes A-F, new cembrane diterpenes from Sinularia flexibilis. Chem. Biodivers. 2009, 6, 2227-2235.

21. Lo, K.-L.; Khalil, A.T.; Chen, M.-H.; Shen, Y.-C. New cembrane diterpenes from Taiwanese soft coral Sinularia flexibilis. Helv. Chim. Acta 2010, 93, 1329-1335.

22. Chen, B.-W.; Su, J.-H.; Dai, C.-F.; Sung, P.-J.; Wu, Y.-C.; Lin, Y.-T.; Sheu, J.-H. Two new cembranes from a Formosan soft coral Sinularia facile. Bull. Chem. Soc. Jpn. 2011, 84, 1371-1373.

23. Shih, H.-J.; Tseng, Y.-J.; Huang, C.-Y.; Wen, Z.-H.; Dai, C.-F.; Sheu, J.-H. Cytotoxic and anti-inflammatory diterpenoids from the Dongsha atoll soft coral Sinularia flexibilis. Tetrahedron 2012, 68, 244-249.

24. Ahmed, A.F.; Wen, Z.-H.; Su, J.-H.; Hsieh, Y.-T.; Wu, Y.-C.; Hu, W.-P.; Sheu, J.-H. Oxygenated cembranoids from a Formosan soft coral Sinularia gibberosa. J. Nat. Prod. 2008, 71, 179-185.

25. Ahmed, A.F.; Tai, S.-H.; Wen, Z.-H.; Su, J.-H.; Wu, Y.-C.; Hu, W.-P.; Sheu, J.-H. A C-3 methylated isocembranoid and 10-oxocembranoids from a Formosan soft coral, Sinularia grandilobata. J. Nat. Prod. 2008, 71, 946-951.

26. Lu, Y.; Huang, C.-Y.; Lin, Y.-F.; Wen, Z.-H.; Su, J.-H.; Kuo, Y.-H.; Chiang, M.Y.; Sheu, J.-H. Anti-inflammatory cembranoids from the soft corals Sinularia querciformis and Sinularia granosa. J. Nat. Prod. 2008, 71, 1754-1759.

27. Lu, Y.; Su, J.-H.; Huang, C.-Y.; Liu, Y.-C.; Kuo, Y.-H.; Wen, Z.-H.; Hsu, C.-H.; Sheu, J.-H. Cembranoids from the soft corals Sinularia granosa and Sinularia querciformis. Chem. Pharm. Bull. 2010, 58, 464-466.

28. Cheng, S.-Y.; Chuang, C.-T.; Wen, Z.-H.; Wang, S.-K.; Chiou, S.-F.; Hsu, C.-H.; Dai, C.-F.; Duh, C.-Y. Bioactive norditerpenoids from the soft coral Sinularia gyrosa. Bioorg. Med. Chem. 2010, 18, 3379-3386.

29. Ahmed, A.F.; Shiue, R.-T.; Wang, G.-H.; Dai, C.-F.; Kuo, Y.-H.; Sheu, J.-H. Five novel norcembranoids from Sinularia leptoclados and S. parva. Tetrahedron 2003, 59, 7337-7344.

30. Tseng, Y.-J.; Ahmed, A.F.; Dai, C.-F.; Chiang, M.Y.; Sheu, J.-H. Sinulochmodins A-C, three novel terpenoids from the soft coral Sinularia lochmodes. Org. Lett. 2005, 7, 3813-3816.

31. Tseng, Y.-J.; Ahmed, A.F.; Hsu, C.-H.; Su, J.-H.; Dai, C.-F.; Sheu, J.-H. New norcembranoids from the soft coral Sinularia lochmodes. J. Chin. Chem. Soc. 2007, 54, 1041-1044.

32. Su, J.-H.; Ahmed, A.F.; Sung, P.-J.; Chao, C.-H.; Kuo, Y.-H.; Sheu, J.-H. Manaarenolides A-I, diterpenoids from the soft coral Sinularia manaarensis. J. Nat. Prod. 2006, 69, 1134-1139. 
33. Ahmed, A.F.; Su, J.-H.; Kuo, Y.-H.; Sheu, J.-H. Scabrolides E-G, three new norditerpenoids from the soft coral Sinularia scabra. J. Nat. Prod. 2004, 67, 2079-2082.

34. Su, J.-H.; Wen, Z.-H. Bioactive cembrane-based diterpenoids from the soft coral Sinularia triangular. Mar. Drugs 2011, 9, 944-951.

35. Sheu, J.-H.; Chang, K.-C.; Sung, P.-J.; Duh, C.-Y.; Shen, Y.-C. Chemical constituents of a Formosan soft coral Sinularia sp. J. Chin. Chem. Soc. 1999, 46, 253-257.

Sample Availability: Not available.

(C) 2012 by the authors; licensee MDPI, Basel, Switzerland. This article is an open access article distributed under the terms and conditions of the Creative Commons Attribution license (http://creativecommons.org/licenses/by/3.0/). 